\title{
Effect of Heat Treatment on the Microstructure of the Alloy AISi7CrMnCu2.5
}

\section{Pavel Kraus, Nataša Náprstková, Klára Jirounková, Jaromír Cais, Jaroslava Svobodová}

Faculty of Machanical Engineering, J. E. Purkyne University in Ústí nad Labem, Pasteurova 3334/7, 400 01, Usti nad Labem. Czech Republic. E-mail: pavel.kraus@ujep.cz, natasa.naprstkova@ujep.cz, k.jirounkova@gmail.com, jaromir.cais@ujep.cz,jaroslava.svobodova@ujep.cz

The article discusses the effect of heat treatment on the microstructure of the aluminum alloy AISi7CrMnCu2.5. Heat treatment of aluminum alloys can be defined as a technological process by which products or components in solid state are exposed to one or more annealing cycles in order to achieve the desired structure. Thanks to these structural changes it is possible to affect the mechanical properties by the hardenable alloy. Samples where the research was conducted were cast from AlSi7CrMnCu2.5 alloy produced by gravity casting technology in metal mold. Subsequently, the castings were subjected to a heat treatment. The microstructure changes of the alloy was investigated by methods of light and electron microscopy.

Keywords: aluminum alloy, heat treatment, morphology, microstructure, intermetallic phase

\section{Introduction}

The precipitation hardening is a heat treatment consisting of the dissolution process (homogenization), annealing and subsequent aging (Fig. 1). From the viewpoint of practical use, it is the most widely used method for heat treatment of Al-Si alloys. Homogenization consists of heating the alloy to the dissolving temperature, holding at this temperature for the time needed for diffusion of alloying elements into solid solution and then cooling with the supercritical speeds. The purpose of this cooling is to convert the solid solution without any significant depletion of alloying elements into the unbalanced state, which creates conditions for the subsequent aging. Optimizing the rate of heating and rate of cooling, as well as a suitable hardening temperature, it is a prerequisite for achieving the desired result of heat treatment. The heating rate and cooling of the dissolution temperature of heating may contribute significantly to changes in shape (distortion), and on the final mechanical properties of castings.

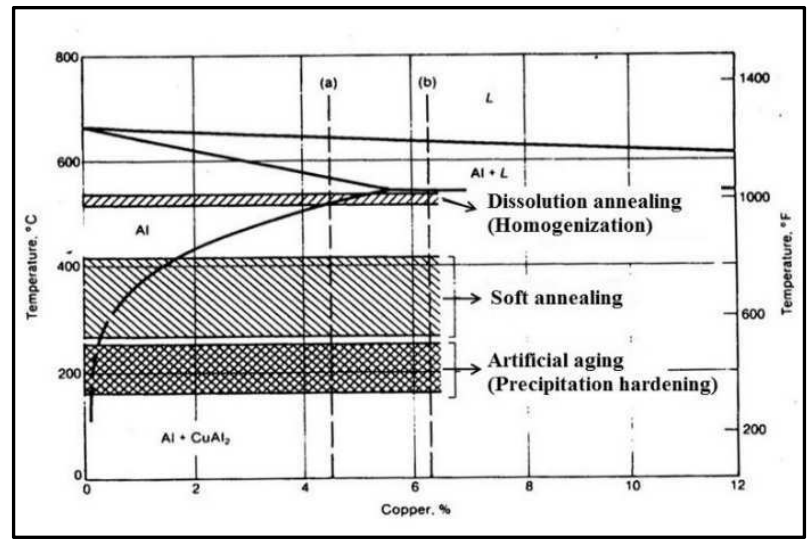

Fig. 1 Diagram of the heat treatment of Al alloys

Holding time at the temperature of dissolution depends upon thickness of the processed casting and initial structure of the material. Cooling is usually execute in water at $20-70^{\circ} \mathrm{C}$. To avoid partial segregation of additives at the grain boundaries, it is necessary to include cooling immediately after holding at the temperature of dissolution annealing. Aging is diffusion process, which occurs in the structure of the casting after homogenization. It leads to depletion of alloying elements in solid solution. Structural changes also occurs during aging process and it leads to changes of mechanical properties. The basic prerequisite for the possibility of curing castings of aluminium alloys is the presence of chemical elements ensuring hardenability (especially $\mathrm{Cu}$ and $\mathrm{Mg}$ ). Feature, which allows the use of the content of these elements for hardening is the change in solubility of Al in solid solution, which dramatically changes with the temperature. $[1,3,4,5]$

\section{Experiment}

Alloy AlSi7CrMnCu2.5 is a polycomponent aluminium alloy. The principal alloying element in the alloy is silicon. Secondary alloying elements are chromium, manganese and copper. The influence of various alloying elements on the properties of the alloy:

Silicon

- improves nearly all the technological properties and foundry properties,

- with increasing silicon content is changed the following characteristics:

○ increases the fluidity,

- reduces the coefficient of shrinkage during solidification,

- reduces the risk of cracks and fissures,

o improving the sliding properties and abrasion resistance,

- reduces the thermal expansion and increases the corrosion resistance.

Chromium

- improves the mechanical properties,

- increases hardenability with curable alloys.

Manganese

- $\quad$ increases strength properties, 
- grain refinement,

- increased sensitivity to curing,

- eliminates the negative effects of iron in the alloy.

Copper

- increases strength and hardness,

- reduces the ductility and deteriorates the corrosion resistance,
- $\quad$ significantly improves machinability,

- $\quad$ enables hardening of the alloy. $[2,5]$

Pure aluminium was used with addition of pure copper and silicon and master alloy AlCr4 and AlMn20 for the preparation of castings. The desired content of alloying elements in the alloy (chemical composition of the castings) is reported in Tab. 1 .

Tab. 1 Chemical composition of the castings

\begin{tabular}{|c|c|c|c|c|c|c|c|c|c|}
\hline Ch. Element & Si & Fe & Cu & Mn & Cr & Mg & Ti & Sr & Al \\
\hline $\begin{array}{c}\text { Content } \\
\text { [wt. \%] }\end{array}$ & 6.893 & 0.263 & 2.487 & 0.612 & 0.491 & 0.041 & 0.052 & $<0.0010$ & base \\
\hline
\end{tabular}

Melting the charge held in a graphite crucible placed in an electric resistance furnace at a temperature of $760^{\circ} \mathrm{C}$. After melting the batch was purified melt through a refining salt and placement of the charge back to the furnace. Subsequent moulding was performed at $720^{\circ} \mathrm{C}$ and a metal mould (preheated to $200^{\circ} \mathrm{C}$ ) with four cylin- drical cavities. The resulting cast was shaped like a cylinder with a diameter of $19 \mathrm{~mm}$ and a length of $210 \mathrm{~mm}$ and a weight of about 180 grams.

Two of the castings was left without a heat treatment (A), and another two castings were subjected to a heat treatment process of the prescribed parameters (B), parameters of heat treatment are listed in Tab. 2.

Tab. 2 Parameters of heat treatment

\begin{tabular}{|c|c|c|c|c|c|}
\hline \multirow[b]{2}{*}{ Variants } & \multicolumn{2}{|c|}{ Homogenization } & \multirow{2}{*}{$\begin{array}{l}\text { Quick cooling - } \\
\text { water tempera- } \\
\text { ture }\left[{ }^{\circ} \mathrm{C}\right]\end{array}$} & \multicolumn{2}{|c|}{ Precipitation hardening } \\
\hline & $\begin{array}{c}\text { Homogenization tem- } \\
\text { perature }\left[{ }^{\circ} \mathrm{C}\right]\end{array}$ & $\begin{array}{c}\text { Staying } \\
\text { [hrs] }\end{array}$ & & $\begin{array}{c}\text { Aging } \\
\text { temperature }\left[{ }^{\circ} \mathrm{C}\right] \\
\end{array}$ & $\begin{array}{c}\text { Aging time } \\
\text { [hrs] }\end{array}$ \\
\hline $\mathbf{A}$ & - & - & - & - & - \\
\hline $\mathbf{B}$ & 530 & 6 & 50 & 190 & 6 \\
\hline
\end{tabular}

Process of homogenization was carried out in an electric resistance furnace at $530^{\circ} \mathrm{C}$ for 6 hours, further followed staying and quenching in water at $50^{\circ} \mathrm{C}$ (cooling tank of 15 litres). Followed by artificial aging process in a laboratory hot-air drier at $190^{\circ} \mathrm{C}$ for 6 hours. The last step was the removal of samples from the dryer and free cooling in air.

\section{Analysis of microstructure}

\subsection{Light microscopy}

Confocal microscope OLYMPUS LEXT OLS 3100 was used for microstructure analysis. Samples of alloys without heat treatment (A) and the samples after heat treatment (B) were analysed.

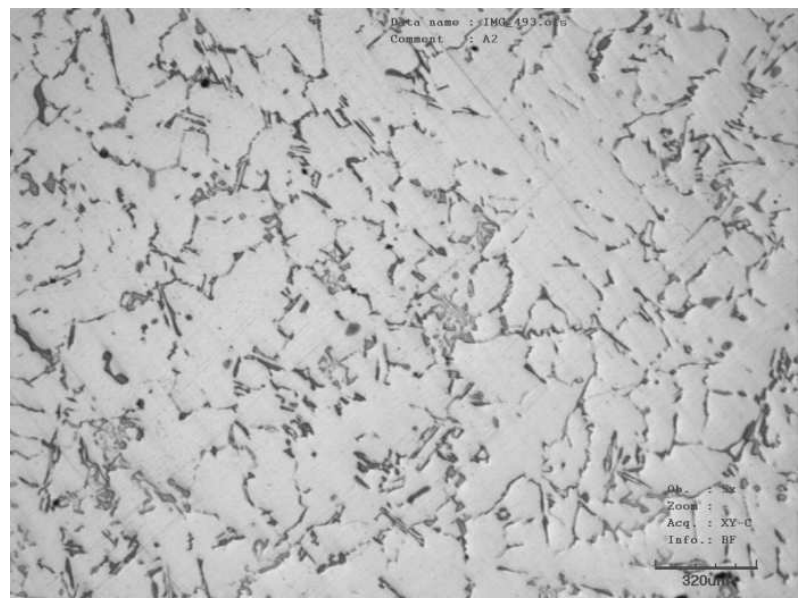

Fig. 2 Alloy without heat treatment

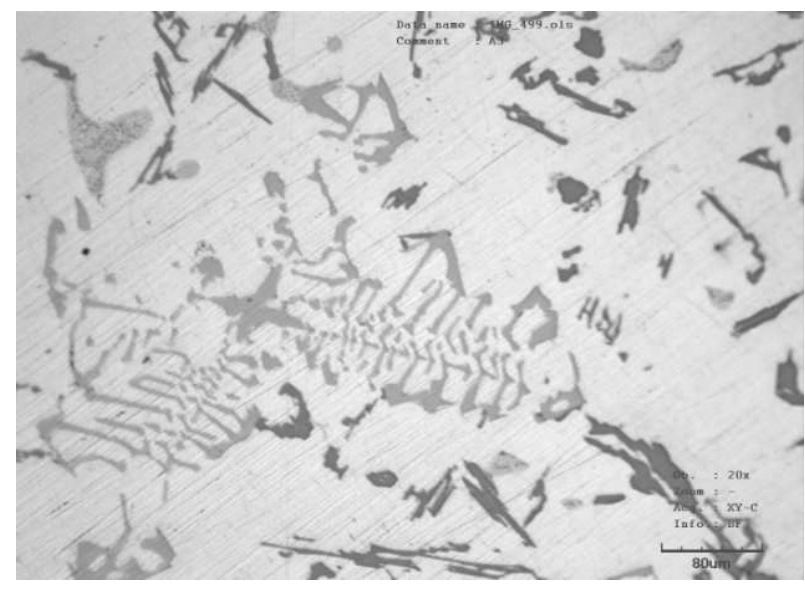

Fig. 3 Alloy without heat treatment-detail

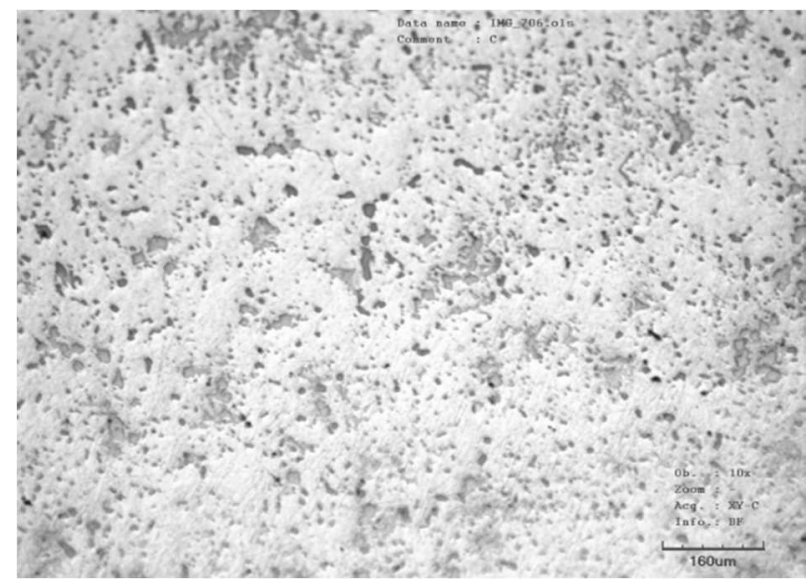

Fig. 4 Alloy after heat treatment 
The microstructure of the alloy is composed of dendritic cells $\alpha$ solid solution and eutectic (mixture of solid solution $\alpha$ and particles of eutectic silicon). Furthermore, in the microstructure was observed different types of intermetallic phases (the result of a high content of alloying elements). Microstructure of the sample without heat treatment is shown in Fig. 2 and 3. The microstructure of the alloy after heat treatment is shown in Fig. 4 and 5.

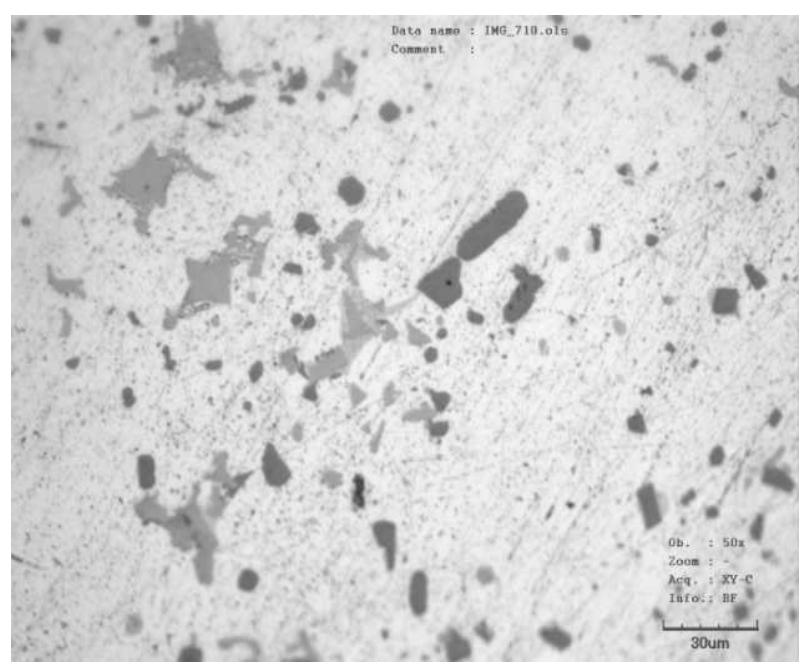

Fig. 5 Alloy after heat treatment

\subsection{SEM and EDS analysis}

The microstructure was analysed with a scanning electron microscope Tescan VEGA 3 complemented by EDS analyser Bruker X-flash.

Fig. 6 shows the structure of sample A without heat treatment, the eutectic silicon phase is visible in the form of needles, coarse phase of copper (Red Point) and the amount of intermetallic polycomponent phases Si-Al-CrMn-Fe. Fig. 7-11 shows the distribution of elements in the structure using the colour-mapping of elements.

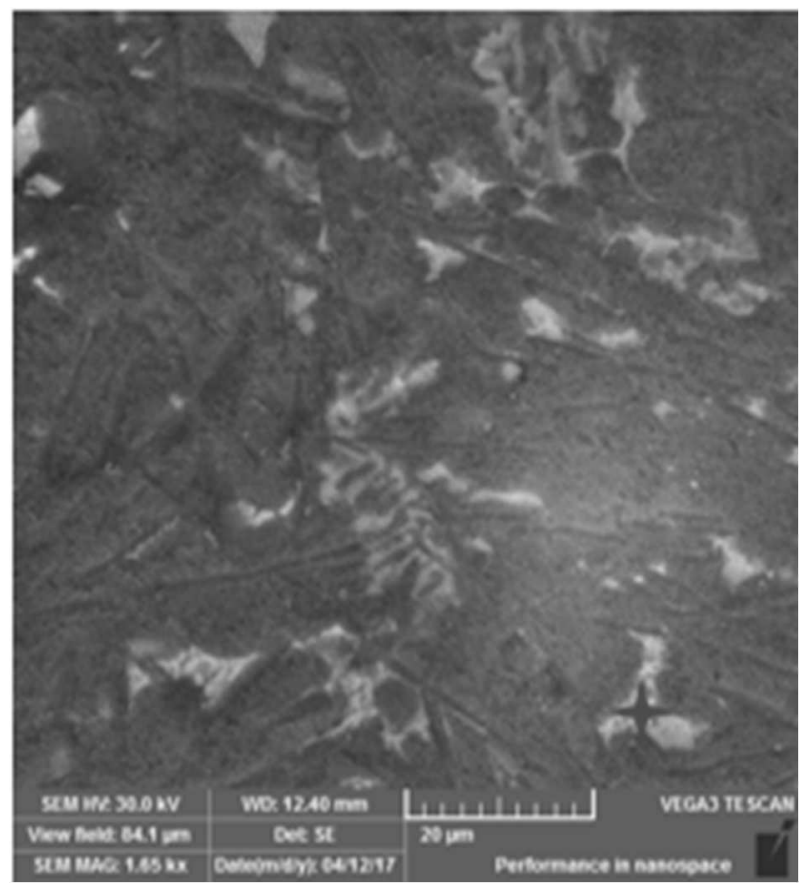

Fig. 6 The structure of sample A

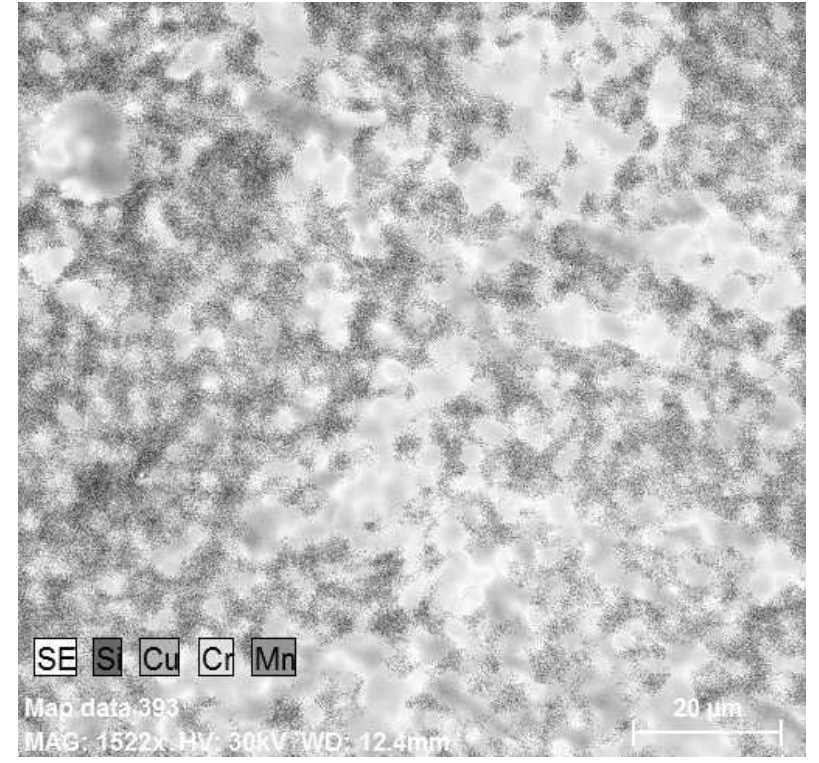

Fig. 7 Colour mapping of elements (A)

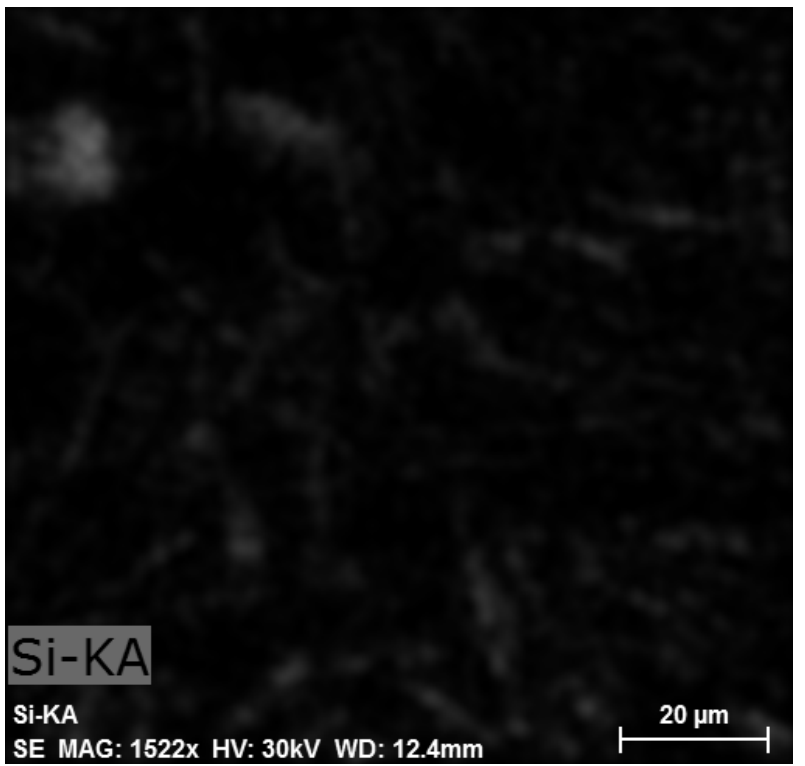

Fig. 8 Colour mapping of $\mathrm{Si}(A)$

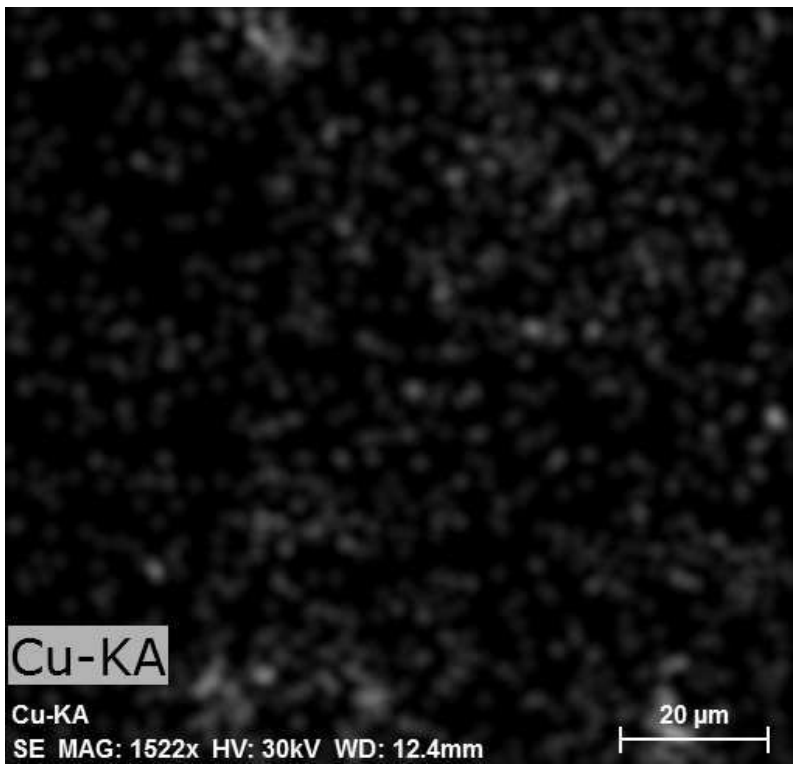

Fig. 9 Colour mapping of $\mathrm{Cu}(A)$ 


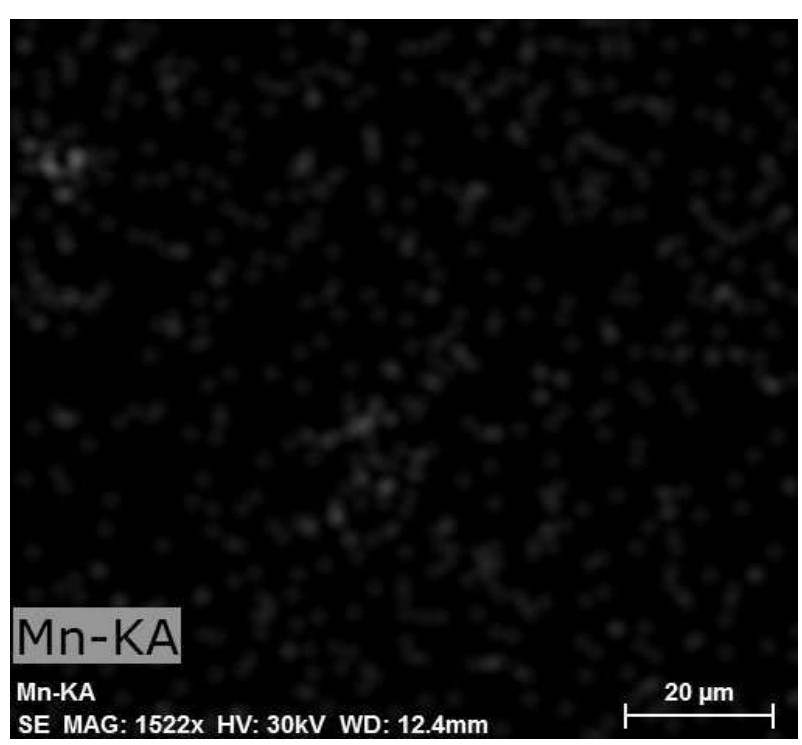

Fig. 10 Colour mapping of $M n(A)$

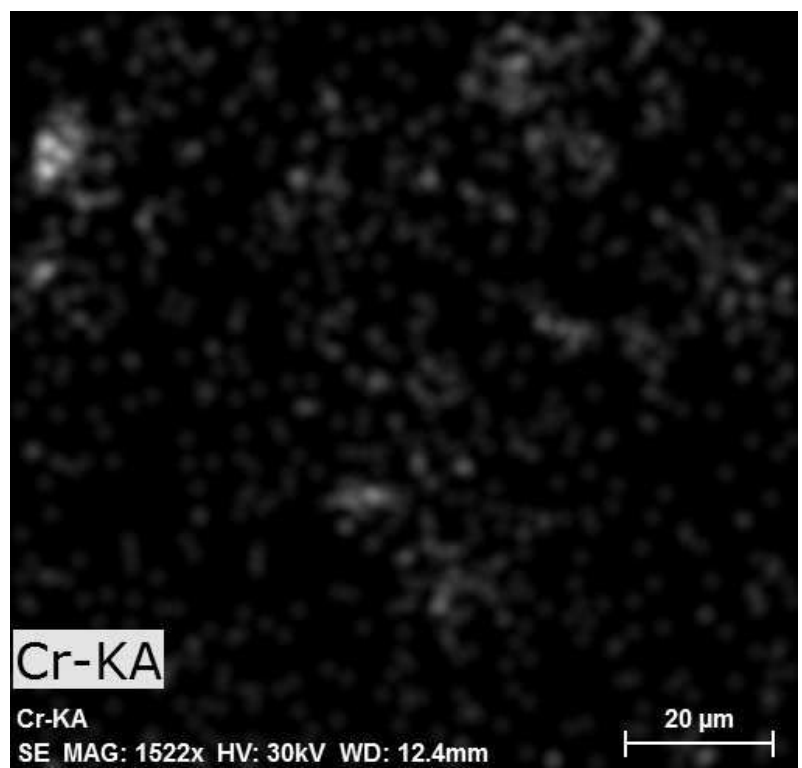

Fig. 11 Colour mapping of $\mathrm{Cr}(A)$

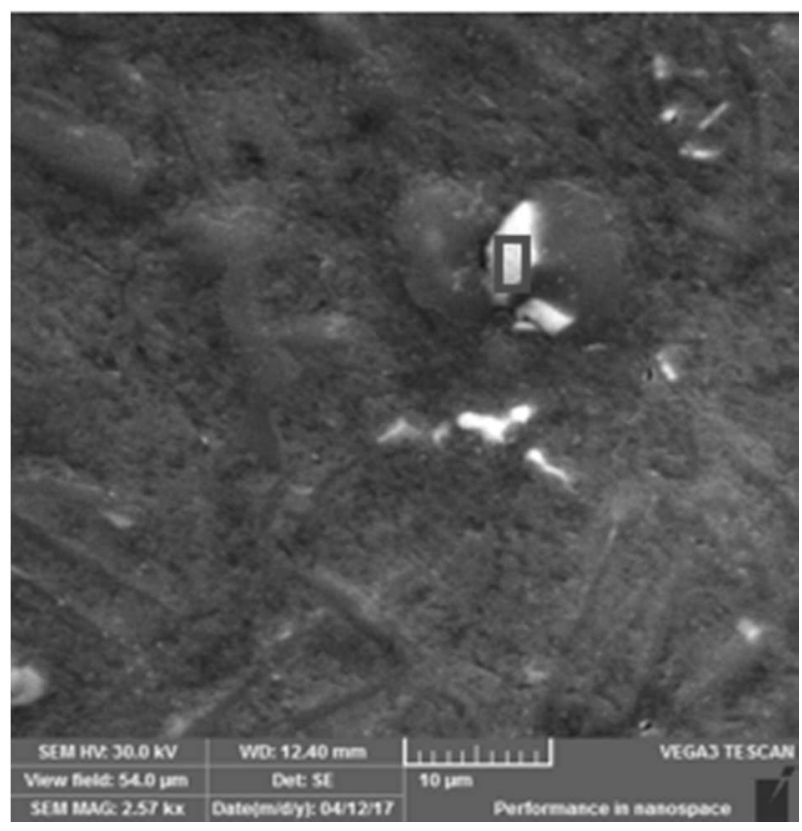

Fig. 12 Intermetallic phase (A)

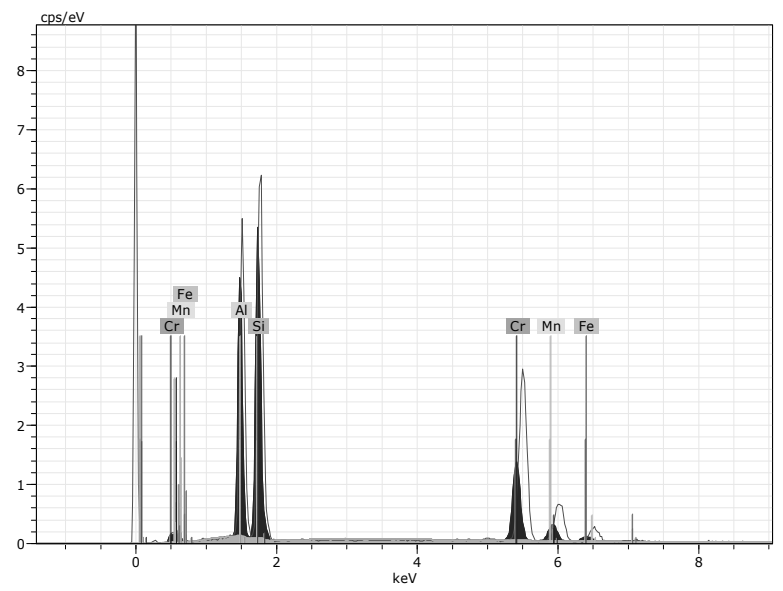

Fig. 13 EDS analysis record

Fig. 12 shows a detail of polycomponent intermetallic phases Si-Al-Cr-Mn-Fe on sample without heat treatment. It was performed the surface EDS analysis of the phase (signed at Fig. 13) and the analysis results are shown in the Tab. 3 .

Tab. 3 Quantification results of EDS analysis (from Fig. 13)

\begin{tabular}{|c|c|c|}
\hline Ch. Element & Content [wt. \%] & Content [at. \%] \\
\hline Silicon & 47.33 & 52.72 \\
\hline Aluminium & 28.22 & 32.71 \\
\hline Chromium & 20.71 & 12.46 \\
\hline Manganese & 2.08 & 1.18 \\
\hline Iron & 1.66 & 0.93 \\
\hline Total & $\mathbf{1 0 0 . 0 0}$ & $\mathbf{1 0 0 . 0 0}$ \\
\hline
\end{tabular}

Fig. 14 shows a detail of polycomponent intermetallic phase Al-Si-Cr-Cu-Fe-Mn for the sample without the heat treatment, the EDS analysis in the marked area (Fig. 15) revealed the results of which are shown in Tab. 4.

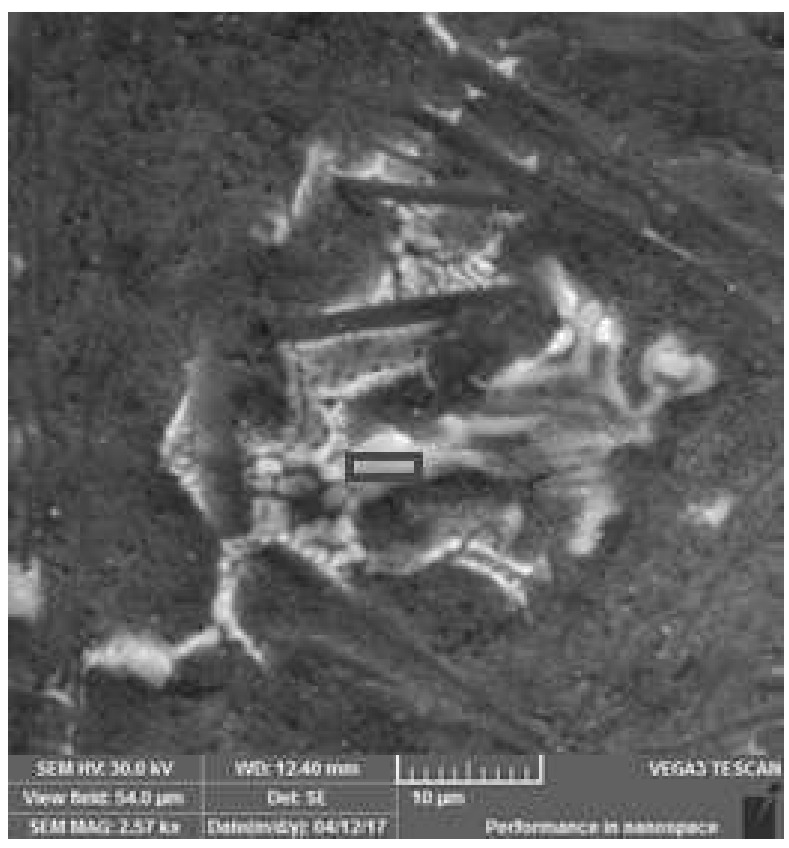

Fig. 14 Intermetallic phase (A) 


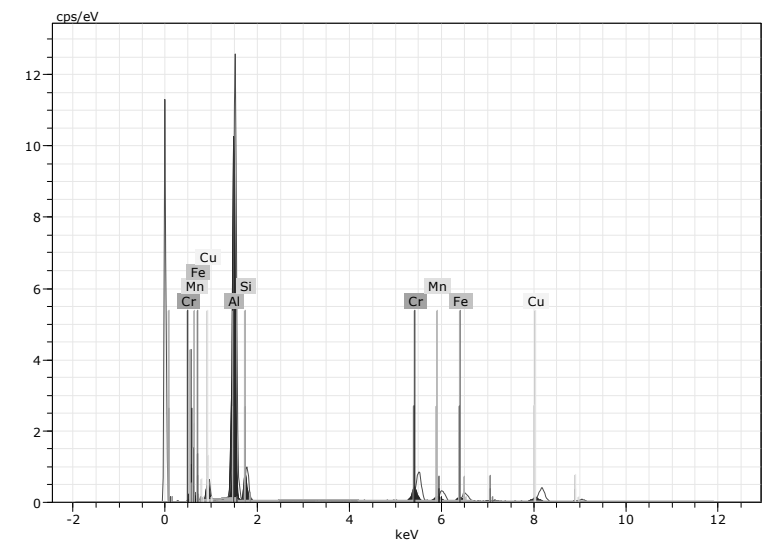

Fig. 15 EDS analysis record

Tab. 4 Quantification results of EDS analysis (from Fig. 15)

\begin{tabular}{|c|c|c|}
\hline Ch. Element & Content [wt. \%] & Content [at. \%] \\
\hline Aluminium & 70.60 & 77.22 \\
\hline Silicon & 13.87 & 14.58 \\
\hline Chromium & 6.99 & 3.97 \\
\hline Copper & 4.53 & 2.11 \\
\hline Iron & 2.13 & 1.13 \\
\hline Manganese & 1.86 & 1.00 \\
\hline Total & $\mathbf{1 0 0 . 0 0}$ & $\mathbf{1 0 0 . 0 0}$ \\
\hline
\end{tabular}

Fig. 16 shows area in which EDS analysis was made of the solid solution matrix of $\alpha$-phase (Fig. 17) which will be further compared with the matrix of the sample after heat treatment. The results of EDS analysis of the matrix indicates the Tab. 5 .

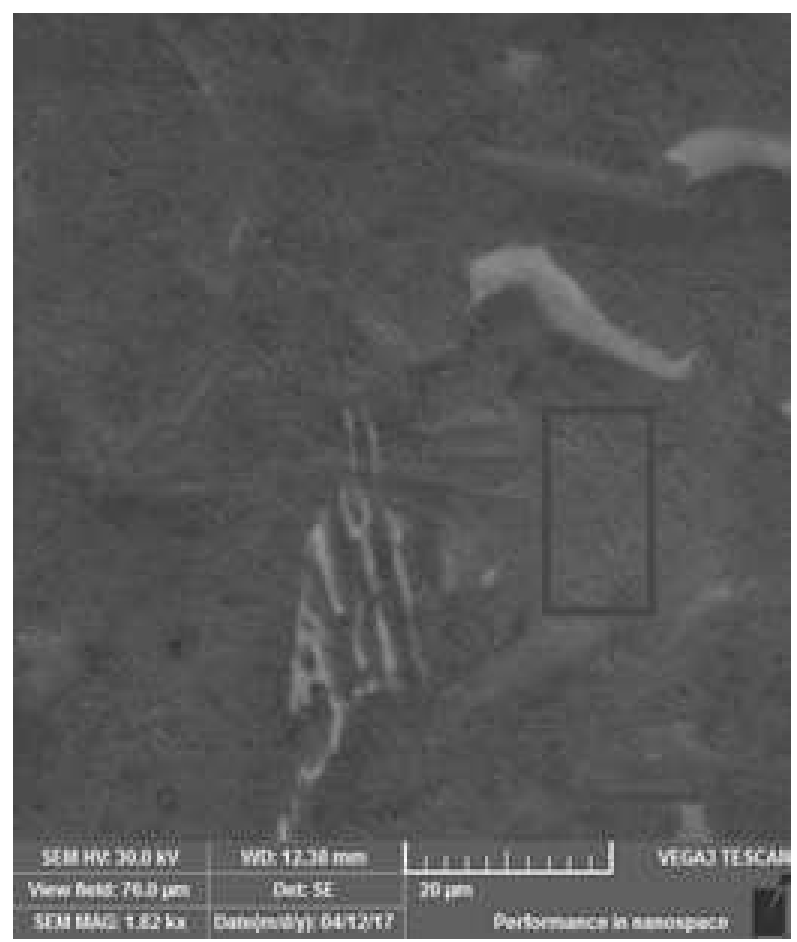

Fig. 16 Intermetallic phase (A)

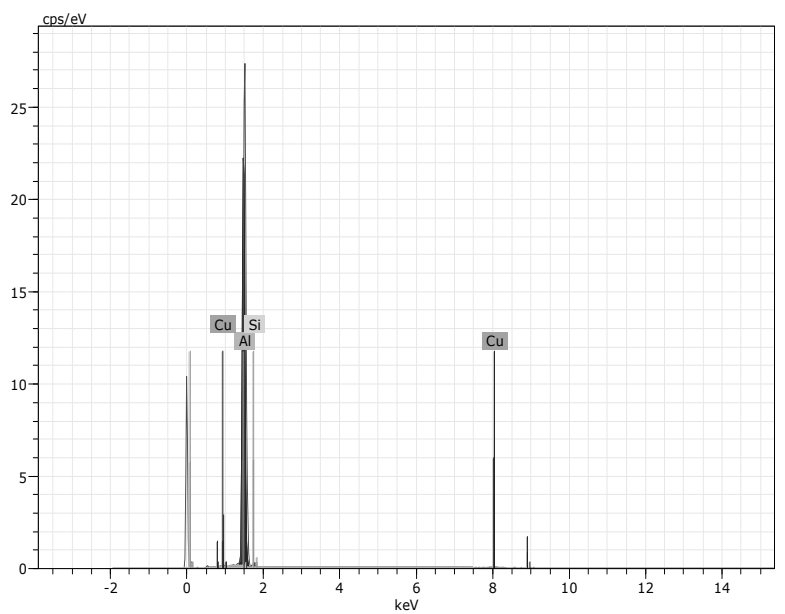

Fig. 17 EDS analysis record

Tab. 5 Quantification results of EDS analysis (from Fig. 17)

\begin{tabular}{|c|c|c|}
\hline Ch. Element & Content [wt. \%] & Content [at. \%] \\
\hline Aluminium & 95.29 & 95.70 \\
\hline Silicon & 4.25 & 4.10 \\
\hline Copper & 0.45 & 0.19 \\
\hline Total & $\mathbf{1 0 0 . 0 0}$ & $\mathbf{1 0 0 . 0 0}$ \\
\hline
\end{tabular}

Samples after heat treatment are at a glance different microstructure as shown Fig. 18. The EDS analysis in Fig. 19 confirms that the coarse eutectic silicon needles are disintegrated into smaller particles globulitic character and split fibres, the chemical composition is shown in Tab. 6

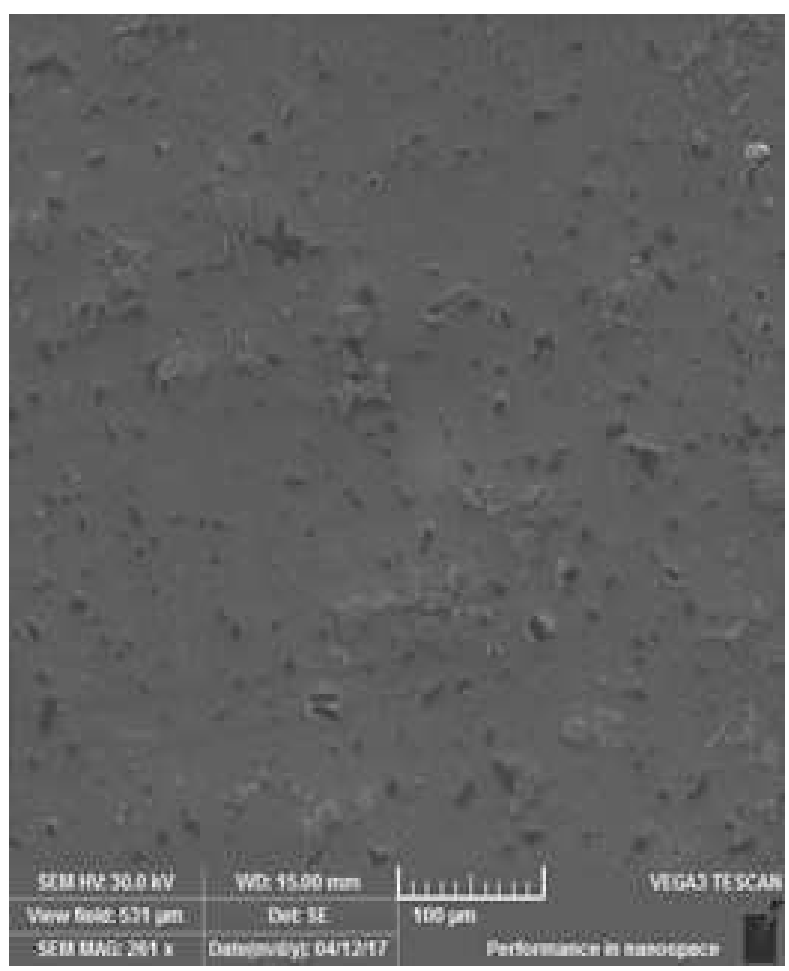

Fig. 18 Microstructure of sample B 


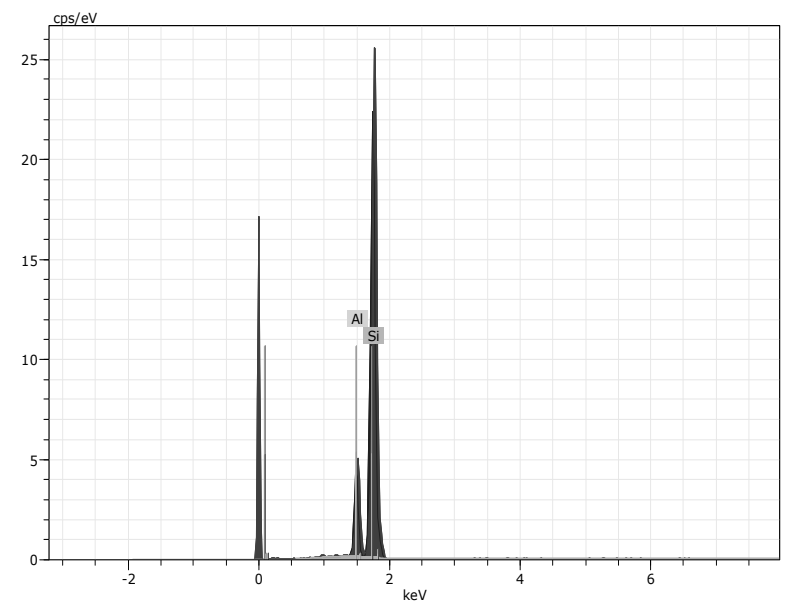

Fig. 19 EDS analysis record

Tab. 6 Quantification results of EDS analysis (from Fig. 19)

\begin{tabular}{|c|c|c|}
\hline Ch. Element & Content [wt. \%] & Content [at. \%] \\
\hline Aluminium & 87.35 & 86.90 \\
\hline Silicon & 12.65 & 13.10 \\
\hline Total & $\mathbf{1 0 0 . 0 0}$ & $\mathbf{1 0 0 . 0 0}$ \\
\hline
\end{tabular}

Intermetallic phases with a high content of copper was dissolved due to homogenization to the solid solution matrix $\alpha$. It is confirmed by the EDS analysis (Fig. 21) of the highlighted area in Fig. 20, which gives accurate results Tab. 7.

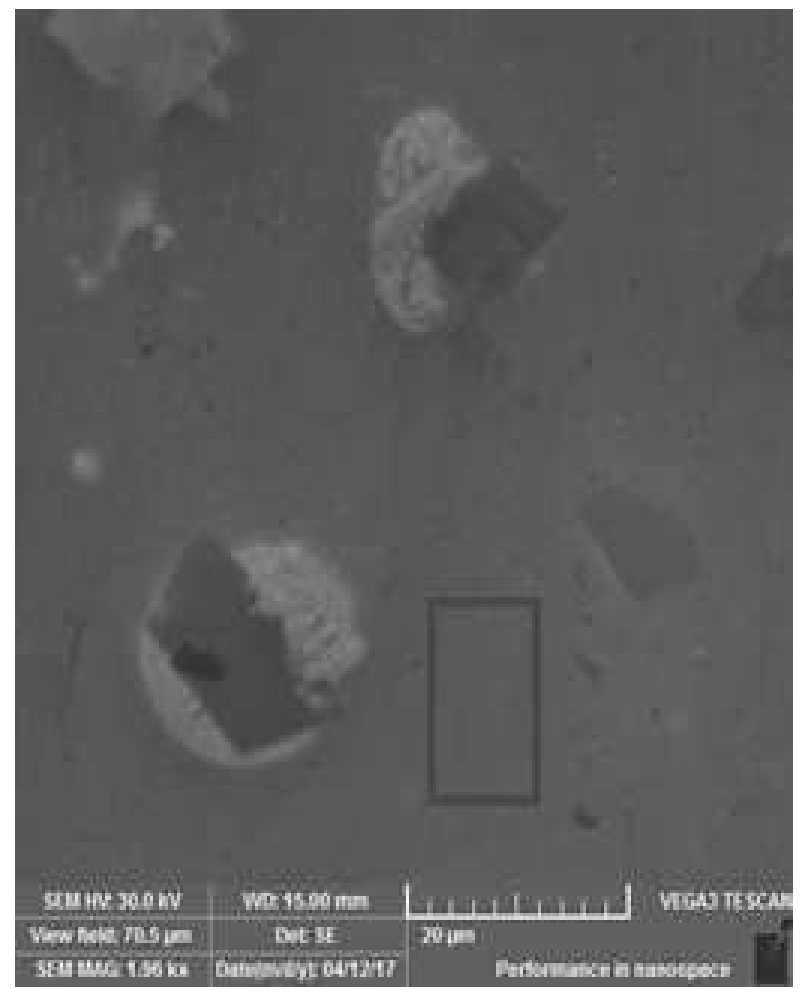

Fig. 20 Intermetallic phase (B)

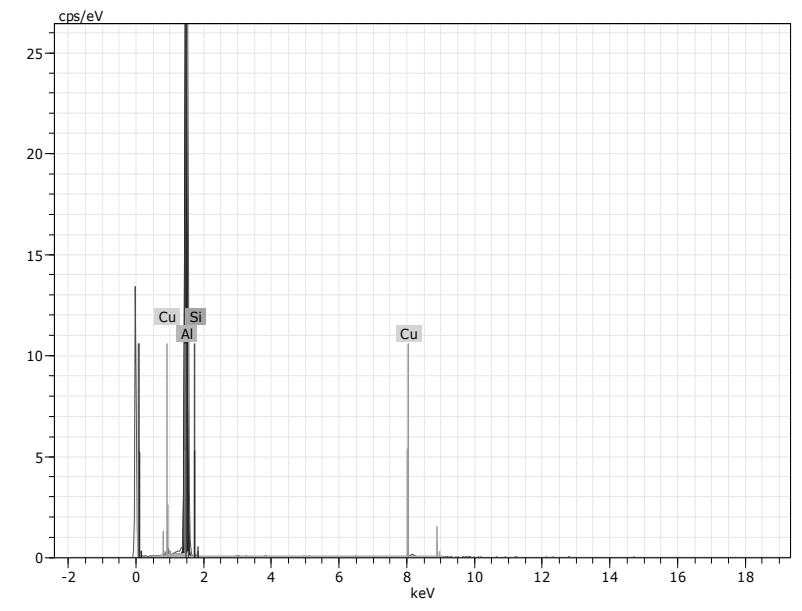

Fig. 21 EDS analysis record

Tab. 7 Quantification results of EDS analysis (from Fig. 21)

\begin{tabular}{|c|c|c|}
\hline Ch. Element & Content [wt. \%) & Content [at. \%] \\
\hline Aluminium & 97.89 & 98.52 \\
\hline Silicon & 1.07 & 1.04 \\
\hline Copper & 1.03 & 0.44 \\
\hline Total & $\mathbf{1 0 0 . 0 0}$ & $\mathbf{1 0 0 . 0 0}$ \\
\hline
\end{tabular}

Copper, which did not dissolve due to the critical cooling rate was attached to the silicon intermetallic phases, grain boundaries and other polycomponent phase, confirming the colour mapping elements and EDS analysis in Fig. 22 to 27.

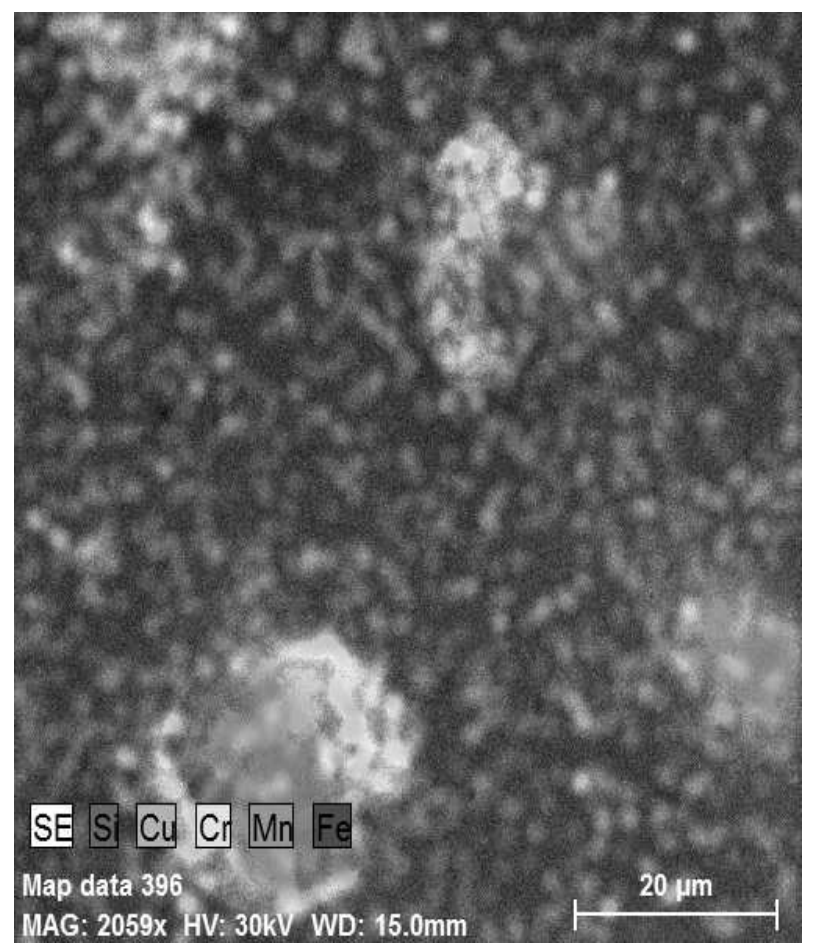

Fig. 22 Colour mapping(B) 


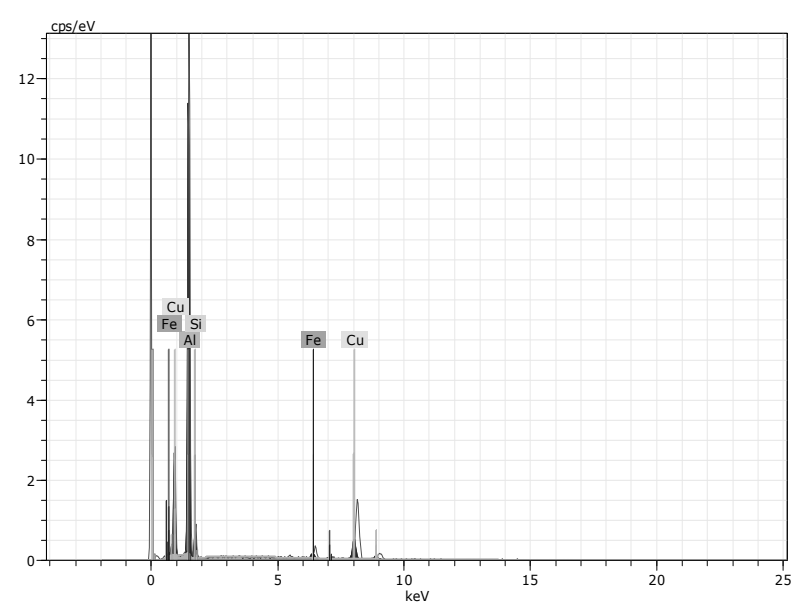

Fig. 23 EDS analysis record

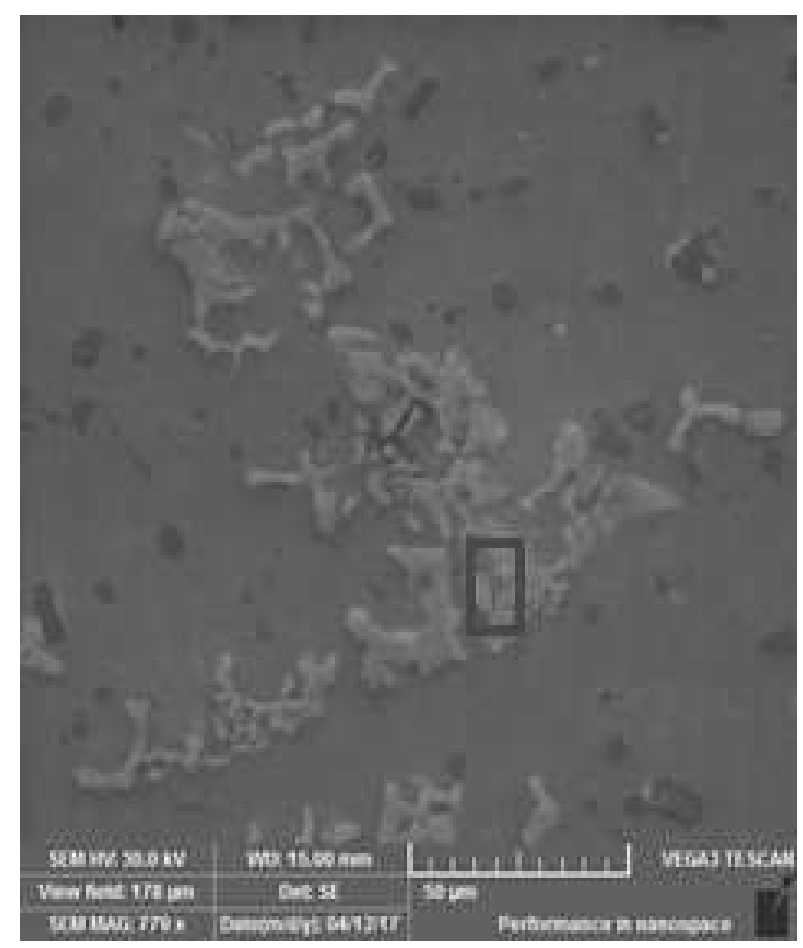

Fig. 24 Intermetallic phase (B)

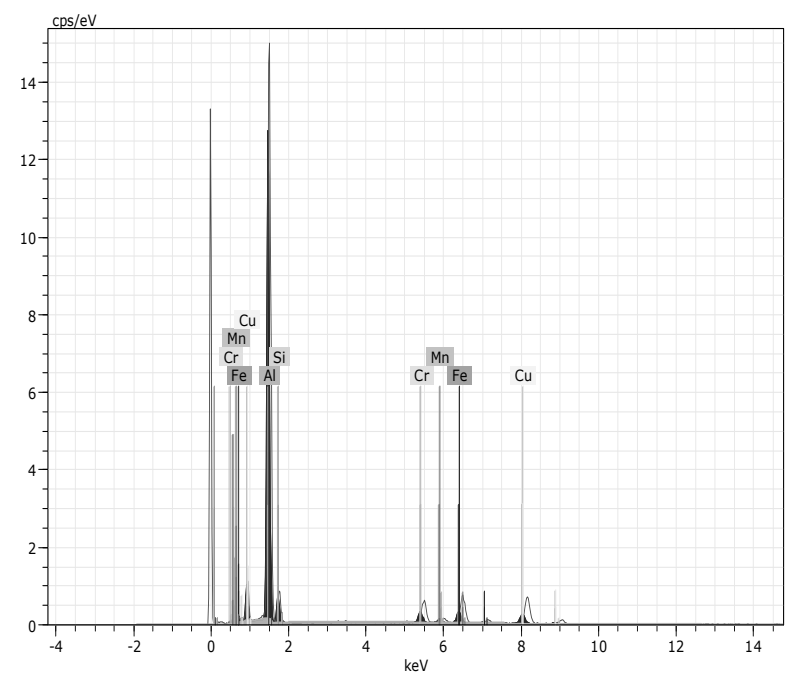

Fig. 25 EDS analysis record

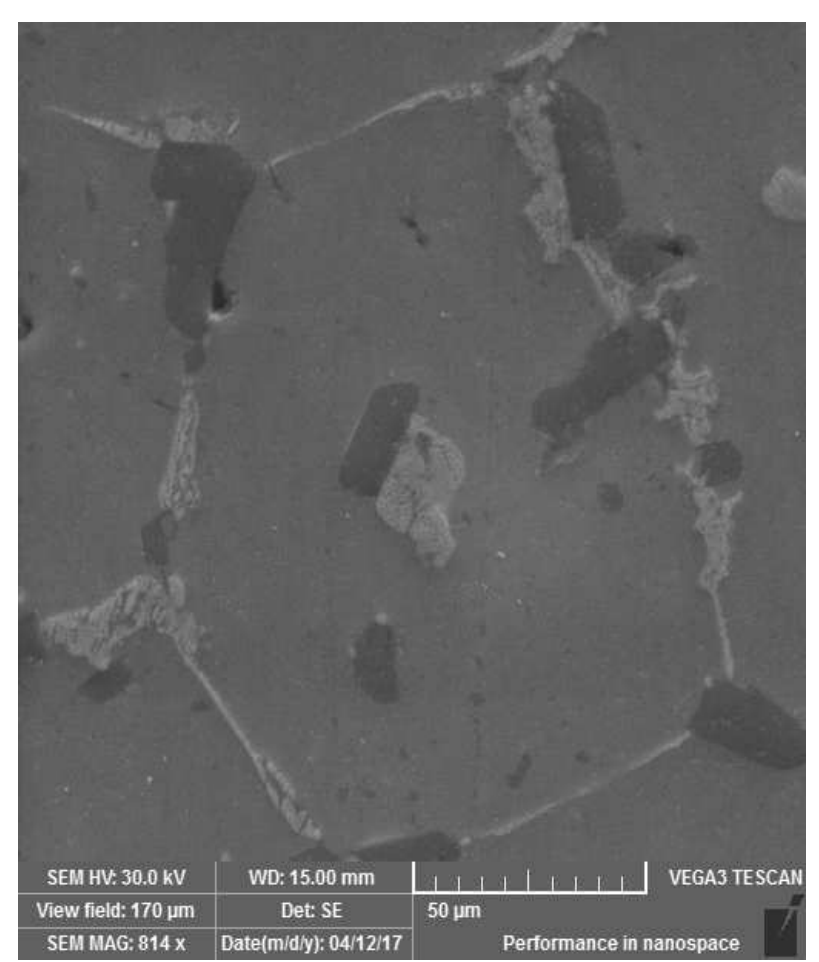

Fig. 26 Grain boundaries (B)

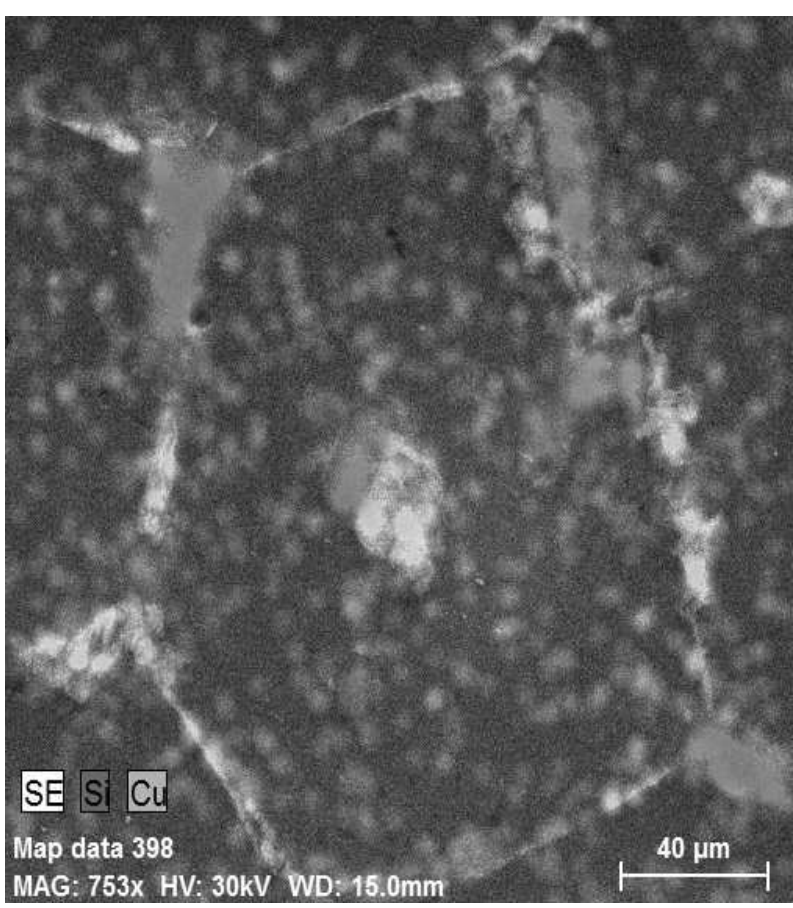

Fig. 27 Grain boundaries - colour mapping (B)

\section{Conclusions}

The aim of the article was the analysis of the heat treatment effect on the AlSi7CrMnCu2.5 alloy microstructure. Light microscopy and SEM/EDS analyses were used for microstructure analysis.

Microstructure of the material without heat treatment showed the presence of substantial amounts of various kinds of intermetallic polycomponent phases due to the large amount of additional elements (alloying elements $\mathrm{Si}, \mathrm{Cu}, \mathrm{Cr}, \mathrm{Mn}$ and undesirable element $\mathrm{Fe}$ ). The eutectic 
silicon was excluded in the microstructure in the form of coarse needles (spatially shaped hexagonal plates).

Effect of heat treatment significantlly changed morphology of eutectic silicon. It leads to the disntegration of coarse particles of silicon and its elimination in the form of fibres and fine spherical particles. Because of this significant change in the microstructure is significant prerequisite for increasing the plasticity of the investigated alloy. Effect of heat treatment also caused the changes in the dimensions of intermetallic phases and their frequency. Lower copper content in the intermetallic phases (or their complete dissolution) after heat treatment is a result of diffusion of this element in the solid solution. We can conclude from the experiment results that this change affect a significant strengthening of the matrix and it will leads to the increasing of the mechanical properties such as strength and hardness, which is also one of the main objectives of the precipitation of aluminium alloys.

\section{References}

[1] LUKÁČ, I., MICHNA, Š., PISARČÍK, T. (2005). Príspevok k problematike tepelného spracovania odlitkoov z Al zliatiny. Sbornik 4. mezinárodní konference ALUMINIUM 2005, s. 130 - 133, ISSN 1335-23341

[2] MICHNA, Š., LUKÁČ, I. A KOL. (2005). Encyklopedie hliniku, 720 str., Adin s.r.o., Prešov SR, 2005, ISBN 80-89041-88-4.
[3] CAIS, J., KRAUS, P., LYSOŇKOVÁ, I. (2017). Influence of the homogenization temperature on the microstructure and properties of AlSi10CuNiMgMn alloy, Adv. Sci. Technol. Res. J. 2017; 11(1):104-110

[4] MONDOLFO, L. F. (1979). Aluminium Alloys, Structure and Properties, Butterworths, London 1979.

[5] ROUČKA, J. Metalurgie neželezných slitin. Brno, Akademické nakladatelství CERM s.r.o., 148s

[6] SLÁNSKÝ, M. (2016). Analýza vlivu vybraného tepelného zpracování na vlastnosti slitiny AlSi7CrMnCu2,5, Diplomová práce, FVTM UJEP 2016

[7] CAIS, J., WEISS, V., SVOBODOVÁ, J. (2015). Influence of Heat Treatment on Microstructure and Mechanical Properties of AlSi9CuMgNiMn Alloy, In Proceedings of the 3rd Internationa Conference on Chemical Technology 2015, s. 253 - 257, ISBN: 978-80-86238-79-1

[8] CAIS, J. (2012). Ovlivňování struktury a vlastností Al - Si slitin pomocí antimonu, Diplomová práce, FVTM UJEP 2012 